\title{
Team Production Effects on Earnings
}

By Todd Idson, Columbia University

Discussion Paper No. 675

December 1993

$$
d p-9394-675
$$




\section{Abstract}

The effects of team production on earnings is examined using the 1973 Quality of Employment Survey. I find that the earnings of nonunion workers are positively related to (1) team size, (2) the extent to which supervisors encourage team work, and (3) the helpfulness of members of the team. These results are robust to controls for establishment size, characteristics of the worker, and both industry and occupation. 


\title{
Team Production Effects on Earnings
}

\author{
Todd L. Idson \\ Columbia University
}

December 1993

I would like to thank, without necessarily implicating, Donald Dewey and Jim Rebitzer for helpful comments. 


\section{Introduction}

This paper examines evidence on the relationship between an employee's earnings and the size of his team of co-workers. In addition, I investigate the effects on earnings of involvement in team production, where a team production setting is indicated by the presence of co-workers who are seen as helpful team members and by the presence of a supervisor who facilitates team interactions.

The possibility that structuring the work environment according to team production methods will have an impact on wages has been recognized in the economics literature. Deardorff and Stafford (1976) theoretically examined the implications for compensation of production in a setting where productive factors must cooperate to produce the product, a situation that is essentially a team production environment. Walter Oi (1990) further developed these ideas as one possible explanation for employer size-wage premia. As Oi noted, since team production requires conformity to a common work environment, "The wages needed to assemble a team are determined by the reservation prices of the marginal team members ... big firms organize production around larger teams and are hence obligated to pay higher wages" (p. S126). To date, though, there have been no empirical studies in the general economics literature of the effect of the size of an employee's work group their wages, possibly due to the paucity of information on co-workers. Furthermore, no evidence has been presented on the relationship between employer size and team size, or the effect of controlling for team size on the measured employer size-wage premium. The primary goal of this paper is to document team effects on wages, including information on the relationship between team 
size and employer size and the extent to which larger teams in larger establishments account for employer size-wage premia.

\section{Data and Variable Description}

There is little data available to evaluate the effects of team size, or team production methods, on worker wages. Fortunately, the 1973 Quality of Employment Survey $(\mathrm{QES})^{1}$ contains sufficient information on individual worker attributes to estimate a standard human capital earnings function, in addition to information about the size of the respondent's team of co-workers and the extent to which the respondent's supervisor encourages team effort. In addition, the QES has information on the size of the establishment where the respondent is employed, so that team effects on earning may be distinguished from employer size effects.

Table 1 reports the definitions of select variables used in this study, and lists means and standard deviations for these variables. The central variable in this paper, the size of the respondent's team of co-workers, is constructed as follows. Respondents were asked the following questions: first, "Is there any group of people that you think of as your co-workers -- people whom you see just about every day and with whom you have to work closely in order to do your job?", and second, "(If respondent has co-workers) About how many people are there in this group?" These two questions are used to construct the team size variable TEAMSZ, which is coded as zero if no group of "co-

\footnotetext{
${ }^{1}$ The 1973 QES contains information on 1,496 individuals residing in the U.S. (excluding households in Alaska and Hawaii) who are 16 years of age or older and who were employed for pay for twenty or more hours per week. The sample is therefore not representative of the entire labor force, but is rather a sample of employed workers.
} 
workers" is indicated, otherwise is coded as the number of co-workers indicated (the top coding for this variable is 97 or more, for which TEAMSZ was set to a value of 97 -only 2 respondents, or $0.3 \%$ of the sample was so coded). The average value of this variable for the 633 nonunion, nonagricultural private sector respondents used in the earnings regressions in Table 3 below is approximately 8.6 workers, with $14.4 \%$ indicating that they are not in a team. ${ }^{2}$

In addition to team size, I have attempted to incorporate into the analysis the effects on earnings of a team production environment per se, as opposed to only looking at the effect of the size of the team. A vector of variables that hopefully reflect a team production environment are described in Table 1. First, TM_WK and TM_IDEA are two dummies which indicate that the respondent feels that his/her supervisor encourages people to work as a team and to exchange ideas relating to work. In addition, another dummy is used, CO_WK, which indicates if the respondent feels that the people he works with are helpful to him in getting his job done. Since this question was not asked in reference to the defined group of co-workers per se, and was asked in a completely different part of the survey, it may additionally capture the presence of a team production environment in the work place -- although admittedly it will be biased in the direction of indicating that a productive team environment is present, rather than team production per se. Nevertheless, while the interpretation of CO_WK may be particularly problematic, the effects on wages of this possible instrument for team production are also

\footnotetext{
${ }^{2}$ The median value for TEAMSZ is 5 , with $31.3 \%$ indicating that they work in a team at or above the mean value of $8.613,11 \%$ responding that they work in a team with greater than twenty member, $5.7 \%$ indicating a team greater than thirty members, and $1.9 \%$ indicating a team with greater than 50 members.
} 
investigated.

\section{Empirical Analysis}

Table 2 looks at the distribution of team size across different size establishments. We see immediately that team size is a positive function of establishment size -- simple univariate statistics reveal that mean team size increases monotonically with the size category of the establishment, though there is substantial variation in team size within different size establishments. Furthermore, a tobit regression was run in order to investigate the relationship between team size and establishment size in a multivariate context. The results reveal that this relationship is robust to controls for worker characteristics, in addition to regional, industry, and occupational controls -- the coefficient (standard error) on LNSIZE in a regression that includes the full set of controls (see the note to Table 3) was $1.671(0.239)$, which is significant at the $1 \%$ level (full results are available on request). This result supports the suggestion by Oi (1990) that larger establishments organize production around larger teams of workers. As a result of the positive association between team and establishment size, it will be necessary to control for size of establishment in earnings regressions in order to see if team size variations within a given size establishment have a significant effect on wages.

Table 3 reports the results of human capital (annual) earnings regressions that incorporate these measures of team size and team production, in addition to controlling for establishment size -- earnings are used as the dependent variable instead of wages because the 1973 QES unfortunately failed to ask weeks worked, so that a wage variable 
cannot be constructed. The analysis has been restricted to nonunion workers since (i) team size was found to have an insignificant effect on wages for union workers, as was TM_WK and CO_WK (though TM_IDEA achieved marginal significance), and (ii) a Chow Test rejected pooling of the union and nonunion sample (the test produced an Fstatistic of 2.796 , which is significant at the $1 \%$ level).

Looking at the first two columns of estimates ${ }^{3}$ we see that part of the well documented establishment size effect on earning (see Brown and Medoff, 1989) is due to team size effects, i.e. the product of the positive correlation between establishment and team size combined with the positive effect of team size on earnings. Nevertheless, the establishment size effect remains significant at $1 \%$ even when team size is controlled for, and even remains significant when the vector of team environment dummies are additionally included in the regression in the last column of estimates. Taken together, these results indicate that the presence of larger teams in larger establishments do account for some of the observed employer size-wage premia, yet the highly significant residual employer size effect indicates that factors other than team size seem to still be operating to form wage premia for nonunion workers in larger establishments.

The results in Table 2 also indicate that team size exerts a significantly positive effect on $(\log )$ annual earnings even when establishment size is controlled for ${ }^{4}$ indicating

\footnotetext{
${ }^{3}$ Note that all specifications reported in Table 2 include a full vector of standard controls, but not surprisingly simple regressions without these controls also yielded significant coefficients for all variables listed in the table (full results available on request).

${ }^{4} \mathrm{~A}$ linear specification of team size is reported since (i) a logarithmic specification was not particularly viable given the large number of respondents with a zero value for TEAMSZ, and (ii) a quadratic specification of team size had no substantively different effect on any of the other variables in the regression, and while jointly significant the linear and quadratic terms were
} 
that team size effects are not simply reflecting employer size effects. The parameter estimates on TEAMSZ indicate that in addition to being statistically significant, the team size effect is nontrivial -- specifically, a one person increase in team size raises annual earnings, on average, by approximately $3.5-4 \%$, and a one standard deviation increase in team size raises annual earnings, on average, by approximately $40 \%$.

Finally, in addition to the effects of team size on wages, we see in the last four columns of Table 3 that our vector of proxies for a team production environment also are all significantly positively related to wages (though TM_IDEA becomes insignificant when all of the team dummies are included in the last specification). The effect of team size slightly declines (in magnitude and significance) when the team environment dummies are added, indicating that part of the estimated team size effect was reflecting simply the presence of team production. Nevertheless, the fact that the coefficient on team size remains significantly positive demonstrates that the size of the team has an independent effect on compensation net of the presence of team production per se.

IV. Alternative Interpretations of the Findings

Two possible factors that might be producing the observed significant residual team effects on wages, in addition to the compensating differential factors suggested by the Deardorff and Stafford model, are (1) efficiency wage payments based on monitoring difficulties in larger teams, and (2) unobserved worker quality that leads to selection into different size teams. Both arguments mirror the discussion that has developed in the

individually insignificant (results available on request). 
literature on employer size effects on wages, and as such will only briefly be discussed here.

The monitoring explanation of employer size wage premia (see Oi, 1983 and 1990; Garen, 1985) suggests that in large firms it is more difficult to accurately observe worker behavior, and as such a profit-maximizing producer will pay wage premia that act to raise the costs to the worker of being dismissed if caught shirking, leading to self-policing on the part of workers. Of course, to the extent that monitoring is mostly done within a work group by the supervisor, the size of the work group may be a better measure of monitoring difficulties than employer size per se. ${ }^{5}$ Hence, workers in larger teams might receive higher wages to produce greater self-policing by raising the value of dismissal threats.

Unobserved quality explanations that have been used as explanations of employer size-wage differentials (see Evans and Leighton, 1989; Idson and Feaster, 1990) would also generate team size wage premium to the extent that (i) higher quality workers sort themselves into work environments with larger teams, and/or (ii) employers who find it beneficial to organize work in a team environment are willing to pay a wage premium for workers with attributes that make them particularly valuable in such a team setting. Specifically, if larger teams require greater interdependence of work, then a premium would be paid (ostensibly made viable by higher team productivity) for workers with such attributes as reliability (see Kremer, 1993). Furthermore, to the extent that workers in

\footnotetext{
${ }^{5}$ Of course, a supervisor may monitor a number of different groups, so that group size might poorly measure monitoring difficulties -- though it is not clear why supervisors in larger establishments would necessarily supervise a greater number of groups.
} 
teams are complementary factors, so that production functions are nonseparable with positive cross-partials in team member inputs (see Alchian and Demsetz, 1972), then higher levels of on-the-job training may be desirable in larger teams, leading to selection of employees based on an imperfectly observed likelihood of successful investment in training. ${ }^{6}$

The lack of team effects in the union sector is consistent with either explanation above. First, since punishment for shirking through wage penalties or being dismissed is harder to implement in the union sector, as would refusal of promotion given the stress on seniority systems, the usage of wage premia to increase the power of dismissal threats is less likely to be justified on efficiency grounds. Second, since wages are attached more to jobs than people in the union sector, particularly able people would be less likely to gravitate toward unions; though attempts on the part of union employers to hold down costs per efficiency unit of labor may lead them to attempt to hire the more productive workers, and unions may be amenable to this if wage premia are thereby easier to justify and maintain.

\section{Conclusions}

This paper has demonstrated that both team size and a team production environment exercise significantly positive effects on wages, and that these effects are independent of establishment size effects on wages. In addition, a number of

\footnotetext{
${ }^{6}$ Arguments based on higher desired levels of on-the-job training that originate in longer-term employment relationships in larger firms (see Idson, 1989 and 1993) would not, though, produce a team size effect (once employer size is controlled for) since failure probabilities and/or opportunities for career advancement within the firm would be unlikely to be correlated with team size per se.
} 
explanations for these finding have been suggested, though as with the literature on employer size effects the data do not readily allow for empirical distinction between these explanations. Specifically, an efficiency wage model is difficult to test with the 1973 QES since information in other data sets that have been used to evaluate an information cost model are not available; there is no direct information on monitoring behavior (see Kruse 1992), piece-rate workers are not represented in the data (see Brown and Medoff, 1989), and there is no distinction between establishment and firm size (see Idson, 1993). Second, the lack of panel information on team size does not allow for a first-difference approach to evaluating the effect of time-invariant, unmeasured ability (see Evans and Leighton, 1989), and the lack of natural instruments to predict participation in team production (or the size of the team that the individual works in, conditional on participation in team production) precludes meaningful estimation of a selection model which treats participation in a team (or in teams of a particular size) as endogenous in the wage regression (see Idson and Feaster, 1990). Nevertheless, a both significant and quantitatively important team size effect has been demonstrated, and it will be the challenge of future studies to attempt to disentangle the various advanced explanations. 


\section{References}

Alchian, A. and H. Demsetz. "Production, Information Cost, and Economic Organization." American Economic Review 62 (December 1972): 777-95.

Brown, Charles and James Medoff. "The Employer Size-Wage Effect." Journal of Political Economy 97 (October 1989): 1027-1059.

Deardorff, A. and F. Stafford. "Compensation of Cooperating Factors." Econometrica 44 (July 1976): 671-84.

Evans, David, and Linda Leighton. "Why Do Smaller Firms Pay Less?" Journal of Human Resources 24 (Spring 1989): 299-318.

Garen, John. "Worker Heterogeneity, Job Screening, and Firm Size." Journal of Political Economy 93 (August 1985): 715-39.

Idson, Todd. "Establishment Size Differentials in Internal Mobility." Review of Economics and Statistics 71 (November 1989): 721-24.

. "Employer Size and Labor Turnover." Columbia University Discussion Paper No. 673, November 1993.

. and Daniel Feaster. "A Selectivity Model of Employer Size Wage Differentials." Journal of Labor Economics 8 (January 1990): 99-122.

Kremer, Michael. "The O-Ring Theory of Economic Development." The Quarterly Journal of Economics 108 (August 1993): 551-575

Kruse, Douglas. "Supervision, Working Conditions, and the Employer Size-Wage Effect." Industrial Relations 31 (Spring 1992): 229-49.

Oi, Walter. "Heterogeneous Firms and the Organization of Production." Economic Inquiry 21 (April 1983): 147-71.

"Employment Relations in Dual Labor Markets ("It's Nice Work If You Can Get It)." Journal of Labor Economics 8 (January 1990): S124-S149. 


\section{Variable Name Variable Description}

TEAMSZ

TM_WK

TM_IDEA

CO_WK

LNSIZE your job." number of people who the respondent indicates are co-workers in his team, defined as "people whom you see just about every day and with whom you have to work closely in order to do

$=1$ if the supervisor "encourages those he/she supervises to work as a team."

$=1$ if the supervisor "encourages those he/she supervises to exchange opinions and ideas."

$=1$ if "The people I work with are helpful to me in getting my job done."

$\log$ of establishment size (number of employees)
4.434

(2.034)

NOTE: The mean (std. dev.) of establishment size are 446.67 (758.52). TEAMSZ is coded to zero if the respondent indicates that he does not have a group of co-workers according to the above definition. The three dummies are coded to zero if TEAMSZ is coded to zero. All statistics are for nonunion, private sector, nonagricultural workers. 
Table 2: The Distribution of Team Size by Size of Establishment

\begin{tabular}{|c|c|c|c|c|c|c|c|}
\hline $\begin{array}{l}\text { Estab. } \\
\text { Size }\end{array}$ & $\frac{1-9}{(131)}$ & $\frac{10-49}{(172)}$ & $\frac{50-99}{(69)}$ & $\frac{100-499}{(120)}$ & $\frac{500-999}{(49)}$ & $\frac{1000-1999}{(31)}$ & $\frac{2000+}{(61)}$ \\
\hline $\begin{array}{l}\text { Team } \\
\text { Size }\end{array}$ & $\begin{array}{c}3.22 \\
(3.63)\end{array}$ & $\begin{array}{c}7.54 \\
(7.77)\end{array}$ & $\begin{array}{r}9.36 \\
(12.13)\end{array}$ & $\begin{array}{r}10.66 \\
(10.75)\end{array}$ & $\begin{array}{c}10.94 \\
(16.59)\end{array}$ & $\begin{array}{c}12.90 \\
(18.24)\end{array}$ & $\begin{array}{c}14.31 \\
(15.78)\end{array}$ \\
\hline
\end{tabular}

NOTE: Cell sizes are reported in parentheses below the plant size category headings. In each cell the mean team size is reported with the standard deviation in parentheses. 
Table 3: Team Production Effects on Earnings 1973 Quality of Employment Survey (Nonunion, $n=633$ )

\begin{tabular}{lcccccc} 
LNSIZE & $0.458^{\mathrm{a}}$ & $0.406^{\mathrm{a}}$ & $0.438^{\mathrm{a}}$ & $0.426^{\mathrm{a}}$ & $0.418^{\mathrm{a}}$ & $0.447^{\mathrm{a}}$ \\
x 10 & $(0.089)$ & $(0.091)$ & $(0.091)$ & $(0.091)$ & $(0.091)$ & $(0.091)$ \\
TEAMSZ & & $0.039^{\mathrm{a}}$ & $0.035^{\mathrm{b}}$ & $0.036^{\mathrm{b}}$ & $0.038^{\mathrm{a}}$ & $0.034^{\mathrm{b}}$ \\
$\quad$ x 10 & & $(0.016)$ & $(0.015)$ & $(0.016)$ & $(0.015)$ & $(0.015)$ \\
TM_WK & & & $0.113^{\mathrm{a}}$ & & & $0.106^{\mathrm{b}}$ \\
& & & $(0.046)$ & & & $(0.051)$ \\
TM_IDEA & & & & $0.078^{\mathrm{b}}$ & & 0.028 \\
& & & $(0.039)$ & & $(0.043)$ \\
CO_WK & & & & & $0.117^{\mathrm{b}}$ & $0.090^{\mathrm{c}}$ \\
& & & & & $(0.050)$ & $(0.051)$ \\
Adj. R R & 0.5844 & 0.5879 & 0.5929 & 0.5899 & 0.5911 & 0.5942 \\
\hline
\end{tabular}

NOTE: All regressions are estimated by ordinary least squares, and additionally contain controls for years of formal education, quadratics in years of general labor market experience and tenure with the current employer, dummies for race, gender, marital status, residence in a SMSA, presence of a health problem that limits the type or amount of work done, three region dummies, nine industry and six occupational dummies at the two-digit level (full results are available on request). Parameter estimates are listed with standard errors in parentheses (superscripts $a, b$, and $c$ denote significance at the $1 \%, 5 \%$, and $10 \%$ levels, respectively). A joint significance test for TM_WK, TM_IDEA, and CO_WK in the last column specification yielded an Fstatistic of 4.10 , which is significant at the $1 \%$ level. 


\section{2-93 DISCUSSION PAPER SERIES \\ Deparment of Economics \\ Columbia University \\ $420 \mathrm{~W} 118$ th St., $1022 \mathrm{IAB}$ \\ New York, NY 10027 \\ Librarian: Ms. Angie Ng}

The following papers are published in the 1992-93 Columbia University Discussion Paper Series which runs from July 1 to June 30. Individual discussion papers are available for purchase at $\$ 5.00$ (U.S.) each for domestic orders and $\$ 8.00$ (U.S.) for foreign orders. Subscriptions to the Series are available at a cost of $\$ 185.00$ (U.S.) per foreign subscription and $\$ 140.00$ (U.S.) per domestic subscription. To order discussion papers, please send your check or money order payable to Department of Economics. Columbia University to the above address. Please make sure to include the series number of the paper when you place an order.

612. Irreversible Choice of Uncertain Technologies with Network Externalities Jay Pil Choi

613. The Real Exchange Rate and U.S. Manufacturing Profits: A Theoretical framework with Some Empirical Support

Richard H. Clarida

614. Cointegration, Aggregate Consumption, and the Demand for Imports: A structural Econometric Investigation

Richard H. Clarida

615. Projecting the Number of New AIDS Cases in the U.S.

David E. Bloom and Sherry Glied

616. Financial Markets for Unknown Risks

Graciela Chichilnisky and Geoffrey M. Heal

617. Financial Innovation and Endogenous Uncerrainty in Incomplete Asset Markets Graciela Chichilnisky and Ho-Mou Wu

618. Arbitrage and Equilibrium in Economies with Infinitely Many Securities and Commodities

Graciela Chichilnisky and Geoffrey M. Heal

619. Market Innovation and the Global Environment Graciela Chichilnisky

$\therefore$

,

620. Option and Non-Use Values of Environmental Assets

Andrea Beltratt1. Gracsela Chichilnisky and Geoffrey Heal 
621. Competition among Institutions

Andrew Caplin and Barry Nalebuff

622. Speculation on Primary Commodities: The Effects of Restricted Entry John McLaren

623. Why did Big Coffee seek regulation? A theory of dynamic monopsony pricing without commitment

John McLaren

624. Speculative Equilibria of "Managed" Primary Commodity Markets Jobn McLaren

625. Income Distribution. Political Instability, and Investment Albero Alesina and Roberto Perorti

n26. The Political Economy of Growth: A Critical Survey of the Recent Literature and Some New Resuits

Alberto Alesina and Roberro Perotri

627. The Term Structure of Forward Exchange Rates and the Forecastability of Spot Exchange Rates: Correcting the Errors

Richard H. Clarida and Mark P. Taylor

628. Why Homelessness? Some Theory Brendan O'Flaherty

629. A Note on Heteroskedasticity Issues Phoebus J. Dhrymes

630. Who Is Bearing the Cost of the AIDS Epidemic in Asia?

David E. Bloom and Sherry Glied

631. Optimal Tariffs and the Choice of Technology: Discriminatory Tariffs vs. the "Most Favored Nation" clause

Jay Pil Choi

632. A Useful Lemma

Phoebus Dhrymes

633. The New Homelessness in North America: Histories of Four Cities Brendan O'Flaherty

634. Burn-Outs: Fire Vicums in North Jersey, the Red Cross, and the Housing Market Brendan O'Flaherty 
635. Labor and the Emerging World Economy

David E. Bloom and Adi Brender

636. Fiscal Policy, Income Distribution, and Growth Roberto Perotri

637. The Political Economy of Redistribution in a Federal System Roberto Perout

638. A Note on Identification Test Procedures

Phoebus Dhrymes

639. The Optimal Income Tax Schedule

Kelvin Lancaster

640. Strategies for Trade Liberalization in the Americas: A Report to ECLAC Gracıela Chichilnisky

641. Robusty Efficient Equilibria in Non-Convex Economies

Graciela Chichilnisky and Geoffrey Heal

642. Financial Markets for Unknown Risks

Graciela Chichilnisky and Geoffrey Heal

643. Price Uncertainty and Derivative Securities in a General Equilibrium Model Graciela Chichilnisky, Jayasri Dutta and Geoffrey Heal

644. North-South Trade and the Dynamics of Renewable Resources

Gractela Chichilnisky

645. Global Environmental Risks

Gracieia Chichilnisky and Geoffrey Heal

646. Chaouc Price Dynamics. Increasing Returns \& the Phillips Curve Graciela Chichilnisky, Geoffrey Heal and Yun Lin

647. Notes on the Political Economy of Nationalism Ronald Findlay

648. Atter Maastricht: Public Investment. Economic Integration, and International Capital Mobility

Richard Clarida and Ronald Findlay

649. Markets. Arbitrage and Social Choices

Graciela Chichilnisky 
650. Limited Arbitrage is Necessary and Sufficient for the Existence of a Competitive Equilibrium

Graciela Chichilnisky

651. Existence of a General Equilibrium with Price Uncertainty

Graciela Chichilnisky

652. Existence of an Optimal Path in a Growth Model with Endogenous Technical Change Graciela Chichiinisky and Paul F. Gruenwald

653. Explaining Economic Growth

David Canning

654. The Effects of Sectoral Decline on the Employment Relationship

Todd L. Idson and Rober G. Valletta

655. U'nemployment and the Economic of Gradualist Policy Reform Michael Gavin

656. Commodity-Price-Destabllizing: Commodity Price Stabilization John Mclaren

657. Executive Compensation and Agency Effects

Todd. L. Idson and Lawerence G. Goldberg

658. Will Free Trade With Political Science Put Normative Economists Out of Work?

Brendan O'Flaherry and Jagdish Bhagwati

659. A characterzzation of Cointegration

Phoebus J. Dhrymes

660. The Production of Human Capital and the Lifecycles of Earnings Jacob Mincer

661. Price Continuity Rules and Insider Trading Prajit K. Dutta

662. On Specifving the Parameters of a Development Plan Prajit K. Dutta

663. Bankruptcy and Expected Utility Maximization

Prajit K. Dutta

664. Moral Hazard

Prajit K. Dutta 
665. Information Aggregation and Strategic Trading in Speculation Prajit K. Dutta

666. Optimal Management of an R\&D Budget Prajit K. Dutta

667. Identification and Kullback Information in the GLSEM Phoebus J. Dhrymes

668. The Influence of Nonmarital Childbearing on the Formation of First Marriages

Neil G. Benner. David Bloom and Cynthia K. Miller

669. A Revealed Preference Approach For Ranking City Quality of Life Matthew Kahn

670. Free Trade: Old and New Challenges

The 1993 Harry Johnson Lecture

Jagdish Bhagwati 


\section{3-94 Discussion Paper Series \\ Department of Economics \\ Columbia University \\ 420 W. 118 St., Room 1022 \\ New York, N.Y., 10027 \\ Librarian: Angie $\mathrm{Ng}$}

The following papers are published in the 1993-94 Columbia University Discussion Paper series which runs from November 1 to October 31. Domestic orders for discussion papers are available for purchase at $\$ 5.00$ (U.S.) each and $\$ 140.00$ (U.S.) for the series. Foreign orders cost $\$ 8.00$ (U.S.) for individual paper and $\$ 185.00$ for the series. To order discussion papers, please send your check or money order payable to Department of Economics, Columbia University to the above address. Please be sure to include the series number for the paper when you place an order.

671. Investment in U.S. Education and Training

Jacob Mincer ( Nov. 1993)

672. Freer Trade and the Wages of the Unskilled: Is Marx Striking Again?

Jagdish Bhagwati and Vivek Dehejia

673. Employer Size and Labor Turnover

Todd Idson

674. Less Crime May Be Worse

Brendan O'Flaherty

675. Team Production Effects on Earnings

Todd Idson

676. Language, Employment. and Earnings in the United States:

Spanish-English Differentials from 1970 to 1990

David Bloom and Gilles Grenier

677. The Impact of Performance Incentives on Providing Job Training to the Poor: The Job Training to the Poor: The Job Training Partnership Act (JTPA)

Michael Cragg

678. The Demands to Reduce Domestic Diversity among Trading Nations Jagdish Bhagwati

679. Mass Layoffs and L'nemployment

Andrew Caplin and John Leahy 
680. The Economics of Adjustment

Andrew Caplin and John Leahy

681. Miracle on Sixth Avenue: Information Externalities and Search

Andrew Caplin and John Leahy

682. Arbitrage. Gains from Trade and Scoial Diversity: A Unified Perspective on

Resource Allocation

Graciela Chichilnisky

683. Who should abate carbon emissions?

Graciela Chichilnisky. Geoffrey Heal

684. Believing in Multiple Equilibria

Graciela Chichilnisky

085. i.imted Arbitrage. Gains trom Trade and Arrow's Theorem

(iraciela Chichilnisky

686. International Emission Permits: Equity and Efficiency

Graciela Chichilnisky. Geoffrey Heal and David Starrett 